\title{
FANCY BIOISOSTERES: NOVEL PARACYCLOPHANE DERIVATIVES AS SUPER-AFFINITY DOPAMINE D3 RECEPTOR ANTAGONISTS
}

\author{
Karin Schlotter, Frank Boeckler, Harald Hübner, and Peter Gmeiner*
}

Table of Contents:

Extended discussion about rotational barriers of the N-methylcarboxamide fragment of the cyclophanes 6a-d and characterization of the main transition state ts between $\mathrm{m} 1$ and $\mathrm{m} 2$

Table S1: Absolute energy [hartree] of the lowest minimum $\mathrm{m} 1$ and relative energy differences $[\mathrm{kcal} / \mathrm{mol}]$ towards the other local minima $\mathrm{m} 2$ and $\mathrm{m} 3$ calculated at increasing levels of theory

Calculation of magnetic shielding properties

Figure S1: Superimposition of the final geometries obtained from DFT calculations for m1, $\mathrm{m} 2$ and $\mathrm{m} 3$

Table S2: Calculated and experimental chemical shifts $(\Delta \delta)[p p m]$ relative to the carbon atom

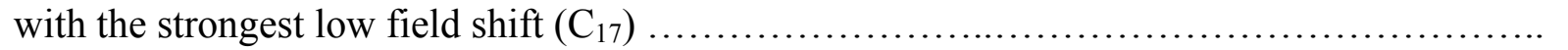

Elemental Analysis and IR Data .... S7

References S8 


\section{Extended discussion about rotational barriers and characterization of the main transition state ts between $\mathrm{m} 1$ and $\mathrm{m} 2$ :}

In comparison to the large rotational barrier which separates the minima $\mathrm{m} 2$ and $\mathrm{m} 3(4.70 \mathrm{kcal} / \mathrm{mol}$ for $\mathrm{m} 3$ and $6.01 \mathrm{kcal} / \mathrm{mol}$ for $\mathrm{m} 2)$, smaller rotational barriers separate $\mathrm{m} 1$ and $\mathrm{m} 2(3.18 \mathrm{kcal} / \mathrm{mol}$ and $1.54 \mathrm{kcal} / \mathrm{mol}$, respectively), as well as $\mathrm{m} 1$ and $\mathrm{m} 3(3.68 \mathrm{kcal} / \mathrm{mol}$ and $0.73 \mathrm{kcal} / \mathrm{mol}$, respectively). As is observable for the transition state of the large rotational barrier, the overlap of the $\pi$-systems is also minimized for the barrier between $\mathrm{m} 1$ and $\mathrm{m} 2$ based on the perpendicular orientation of the amide and the cyclophane. However, for this smaller rotational barrier, the carbonyl oxygen approaches the hydrogen in the second aromatic layer with a larger distance $(\sim 2.5 \AA)$ as found for the large barrier $(\sim 1.9 \AA)$. The third rotational barrier between $\mathrm{ml}$ and $\mathrm{m} 3$ is unlike the others not caused by disruption of the $\pi$-conjugation, but by unfavorable sterical interactions. The dististance of the carbonyl oxygen towards one of the hydrogens in the adjacent ethano-bridge $\left(\mathrm{d}_{\mathrm{H} . . \mathrm{O}} \sim 2.3 \AA\right)$, as well as between the amide hydrogen and a proximate hydrogen in the aromatic system $\left(\mathrm{d}_{\mathrm{H} . . . \mathrm{H}} \sim 1.9 \AA\right)$ fall both short of the sum of the atoms' van der Waals radii.

In addition, the structure of the transition state between $\mathrm{m} 1$ and $\mathrm{m} 2$ for the rotation around $\Phi_{3-4-17-18}$ was calculated at the $6-311 \mathrm{G}(\mathrm{d})$ level of theory. The fact that a real transition state was found was verified by frequency calculation, which yielded only one negative frequency $\left(-51 \mathrm{~cm}^{-1}\right)$ corresponding to the examined rotational motion. The energy of the transition state was found to be $2.67 \mathrm{kcal} / \mathrm{mol}$ higher than the $\mathrm{m} 1$-state and $1.26 \mathrm{kcal} / \mathrm{mol}$ higher than the $\mathrm{m} 2$-state. Corresponding to the Boltzmann equation, the maximal activation energy of $2.67 \mathrm{kcal} / \mathrm{mol}$ allows for a population of the transition state of $>1 \%$, thus, demonstrating that a certain transition probability exists between the $\mathrm{m} 1$ and the $\mathrm{m} 2$ state at room temperature.

Table S1. Absolute energy [hartree] of the lowest minimum $\mathrm{m} 1$ and relative energy differences $[\mathrm{kcal} / \mathrm{mol}]$ towards the other local minima $\mathrm{m} 2$ and $\mathrm{m} 3$ calculated at increasing levels of theory

\begin{tabular}{lccc} 
density functional / basis set & $\mathrm{E}_{\mathrm{m} 1}$ [hartree $]$ & $\Delta \mathrm{E}_{\mathrm{m} 2-\mathrm{m} 1}[\mathrm{kcal} / \mathrm{mol}]$ & $\Delta \mathrm{E}_{\mathrm{m} 3-\mathrm{m} 1}[\mathrm{kcal} / \mathrm{mol}]$ \\
\hline B3LYP / 6-311G(d) ${ }^{\mathrm{a}}$ & -827.4928219740 & +1.42 & +3.26 \\
B3LYP / 6-311+G(d,p) & -827.5311793230 & +1.24 & +2.65 \\
B3PW91 / 6-311+G(2d,p) & -827.2271711320 & +1.24 & +2.56 \\
B3LYP / 6-311+G(2df,2p) & & +1.29 & +2.57 \\
B3PW91 / 6-311+G(2df,2p) & -827.5811591680 & +1.25 & +2.51
\end{tabular}

\footnotetext{
${ }^{\mathrm{a}}$ full optimization

${ }^{\mathrm{b}}$ single point calculation on previously minimized structure
} 


\section{Calculation of magnetic shielding properties:}

To evaluate the quality of the preferential structures resulting from DFT calculations and to gain further evidence for the putative bioactive conformations, we have checked the conformity of their calculated magnetic shielding versus experimental NMR data. Therefore, we calculated the magnetic shielding tensor using gauge invariant atomic orbitals ${ }^{1}$ (GIAO) within B3PW91 / 6-311+G(2d,p) or B3PW91 / 6-311+G(2df,2p) single point calculation. The different orientations of the carboxamide in the three investigated conformational states and, thus, their changes of the local magnetic field by statespecific proximities to certain carbon atoms were used as a criterion to compare experimental with calculated ${ }^{13} \mathrm{C}-\mathrm{NMR}$ data. Employing them as "state-specific NMR-probes", we further considered the 11 carbon atoms which are adjacent to the varying dihedral angle $\left(\mathrm{C}_{1}, \mathrm{C}_{2}, \mathrm{C}_{3}, \mathrm{C}_{4}, \mathrm{C}_{5}, \mathrm{C}_{6}, \mathrm{C}_{11}, \mathrm{C}_{12}, \mathrm{C}_{13}\right.$, $\mathrm{C}_{14}$ and $\mathrm{C}_{17}$ as depicted in Figure S1) and calculated their chemical shifts by subtraction of the total shielding (average isotropic value) of the respective carbon atom from the total shielding of a TMScarbon atom:

$$
\delta_{x \in\left\{C_{1}, C_{2}, C_{3}, C_{4}, C_{5}, C_{6}, C_{11}, C_{12}, C_{13}, C_{14}, C_{17}\right\}}=\sigma_{T M S}-\sigma_{X} ;
$$

TMS as a reference was optimized and subjected to NMR single point calculations on the same levels as the compared structures utilizing its $T_{d}$-symmetry. To avoid method-based systematic deviations in the prediction of the absolute chemical shift values, the use of relative differences of the shift values $(\Delta \delta)$, taking the carbon atom with the strongest low field shift $\left(\mathrm{C}_{17}\right)$ as a reference point, has proven to be more useful for the comparison with experimental data (Table S2).,3

The average differences between calculated $\left(\Delta \delta_{\text {calc }}\right)$ and experimental relative chemical shifts $\left(\Delta \delta_{\text {exp }}\right)$ were obtained to be $1.7 \mathrm{ppm}$ for the m1-conformer, $2.3 \mathrm{ppm}$ for the $\mathrm{m} 2$ conformer and $4.2 \mathrm{ppm}$ for the $\mathrm{m} 3$ conformer at the $6-311+\mathrm{G}(2 \mathrm{~d}, \mathrm{p})$-level. Thus, the pattern of chemical shifts of the m1 conformer exhibits the best match to the pattern found in the experimental data. The deviation for $\mathrm{m} 2$ is somewhat increased, while $\mathrm{m} 3$ shows the worst match to the experimental data with a considerably increased deviation. Likewise, at the $6-311+\mathrm{G}(2 \mathrm{df}, 2 \mathrm{p})$-level the average differences $\left(\sum\left|\Delta \delta_{\text {calc }}-\Delta \delta_{\text {exp }}\right|\right) / \mathrm{n}$ were determined to be $1.8 \mathrm{ppm}, 1.8 \mathrm{ppm}$ and $3.5 \mathrm{ppm}$ for $\mathrm{m} 1, \mathrm{~m} 2$ and $\mathrm{m} 3$, respectively. Thus, looking at the average values, the $\mathrm{m} 1$ and $\mathrm{m} 2$ state correspond equally well to the experimental data at the higher level of calculation. The degree of hybridization is known to be one of the parameters exerting considerably high influence on the chemical shift of a carbon atom. As the torsional angle $\Phi_{3-4-17-18}$ strongly influences the hybridisation and electron distribution at the carbon atoms $\mathrm{C}_{4}$ and $\mathrm{C}_{17}$, we have additionally focussed on the correspondance of their relative shift with the experiment data. At both levels of calculation $(6-311+\mathrm{G}(2 \mathrm{~d}, \mathrm{p})$ and $6-311+\mathrm{G}(2 \mathrm{df}, 2 \mathrm{p}))$, $\mathrm{m} 1$ represents the experimental values best with a deviation of only 0.9 and $1.4 \mathrm{ppm}$, respectively. Again, $\mathrm{m} 2$ shows an increased deviation (4.3 and $3.6 \mathrm{ppm}$ ), while $\mathrm{m} 3$ exhibits the least match to the experimental values with a deviation of 6.3 and $5.3 \mathrm{ppm}$. Thus, also comparison between the theory-based calculations and the experimental ${ }^{13} \mathrm{C}-\mathrm{NMR}-$ data suggests a preference for the $\mathrm{m} 1$ conformer, although it is possible that the $\mathrm{m} 2$ conformation plays also a role at room or body temperature. 


\section{Figure S1:}

Superimposition of the final geometries obtained from DFT calculations for $\mathrm{m} 1, \mathrm{~m} 2$ and $\mathrm{m} 3$. Atoms indicated with yellow spheres were selected as probes for comparison of the calculated and experimental relative chemical shifts based on differences in the magnetic shielding which are caused by proximity to the carboxamide function and its varying orientation in the three different states $\mathrm{m} 1-\mathrm{m} 3$.

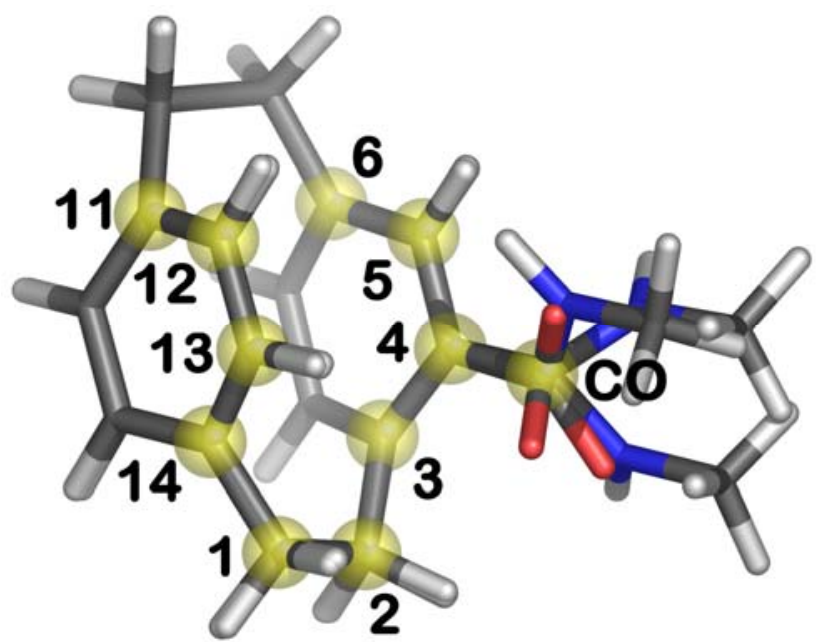


Table S2. Calculated (for $\mathrm{m} 1, \mathrm{~m} 2$ and $\mathrm{m} 3$ ) and experimental chemical $\operatorname{shifts}^{a}(\Delta \delta)[p p m]$ relative to the carbon atom with the strongest low field shift $\left(\mathrm{C}_{17}\right)$

\begin{tabular}{|c|c|c|c|c|c|c|c|c|}
\hline & \multicolumn{4}{|c|}{ B3PW91/6-311+G(2d,p) } & \multicolumn{4}{|c|}{ B3PW91/6-311+G(2df,2p) } \\
\hline & $\mathrm{ml}$ & $\mathrm{m} 2$ & $\mathrm{~m} 3$ & exp. $^{a}$ & $\mathrm{~m} 1$ & $\mathrm{~m} 2$ & $\mathrm{~m} 3$ & exp. $^{a}$ \\
\hline$\delta\left(\mathrm{C}_{17}\right)-\delta\left(\mathrm{C}_{1}\right)$ & 135.3 & 133.6 & 131.7 & 134.0 & 135.7 & 133.9 & 132.1 & 134.0 \\
\hline$\delta\left(\mathrm{C}_{17}\right)-\delta\left(\mathrm{C}_{2}\right)$ & 135.0 & 133.6 & 131.5 & 134.7 & 135.5 & 134.0 & 132.4 & 134.7 \\
\hline$\delta\left(\mathrm{C}_{17}\right)-\delta\left(\mathrm{C}_{3}\right)$ & 24.4 & 29.9 & 20.1 & 30.5 & 24.9 & 30.5 & 20.7 & 30.5 \\
\hline$\delta\left(\mathrm{C}_{17}\right)-\delta\left(\mathrm{C}_{4}\right)$ & 35.1 & 29.9 & 27.9 & 34.2 & 35.6 & 30.6 & 28.9 & 34.2 \\
\hline$\delta\left(\mathrm{C}_{17}\right)-\delta\left(\mathrm{C}_{5}\right)$ & 39.5 & 34.3 & 36.0 & 37.7 & 39.3 & 34.5 & 36.5 & 37.7 \\
\hline$\delta\left(\mathrm{C}_{17}\right)-\delta\left(\mathrm{C}_{6}\right)$ & 28.3 & 25.9 & 25.8 & 29.3 & 28.6 & 26.6 & 26.5 & 29.3 \\
\hline$\delta\left(\mathrm{C}_{17}\right)-\delta\left(\mathrm{C}_{11}\right)$ & 30.3 & 27.2 & 25.4 & 30.3 & 30.6 & 27.7 & 26.2 & 30.3 \\
\hline$\delta\left(C_{17}\right)-\delta\left(C_{12}\right)$ & 38.1 & 34.9 & 36.4 & 37.0 & 38.9 & 35.3 & 37.0 & 37.0 \\
\hline$\delta\left(C_{17}\right)-\delta\left(C_{13}\right)$ & 38.0 & 34.5 & 35.2 & 37.0 & 38.1 & 35.1 & 35.9 & 37.0 \\
\hline$\delta\left(\mathrm{C}_{17}\right)-\delta\left(\mathrm{C}_{14}\right)$ & 26.5 & 27.8 & 22.5 & 29.6 & 26.9 & 28.4 & 23.0 & 29.6 \\
\hline$\left(\sum \mid \Delta \delta_{\text {calc }^{-}}\right.$ & 1.7 & 2.3 & 4.2 & & 1.8 & 1.8 & 3.5 & \\
\hline$\left.\Delta \delta_{\exp } \mid\right) / \mathbf{n}$ & & & & & & & & \\
\hline
\end{tabular}

\footnotetext{
${ }^{a}$ Assignment of signals in ${ }^{1} \mathrm{H}$ and ${ }^{13} \mathrm{C}$ spectra was established by $\mathrm{H}-\mathrm{H}-\mathrm{COSY}$ and heteronuclear correlation spectra (HSQC, HMBC, dept 90)
} 
Elemental Analysis Data:

\begin{tabular}{|c|c|c|c|c|c|}
\hline Compound & Formula & & $\mathrm{C}(\%)$ & H (\%) & $\mathbf{N}(\%)$ \\
\hline \multirow{2}{*}{4} & \multirow{2}{*}{$\mathrm{C}_{34} \mathrm{H}_{39} \mathrm{~N}_{3} \mathrm{O}_{3}$} & Calcd & 75.95 & 7.31 & 7.81 \\
\hline & & Found & 75.96 & 7.37 & 7.80 \\
\hline \multirow{2}{*}{$\mathbf{6 a}$} & \multirow{2}{*}{$\mathrm{C}_{32} \mathrm{H}_{39} \mathrm{~N}_{3} \mathrm{O}_{2} 0.3 \mathrm{H}_{2} \mathrm{O}$} & Calcd & 76.40 & 7.93 & 8.35 \\
\hline & & Found & 76.54 & 7.91 & 8.41 \\
\hline \multirow{2}{*}{$(S)-6 \mathbf{a}$} & \multirow{2}{*}{$\mathrm{C}_{32} \mathrm{H}_{39} \mathrm{~N}_{3} \mathrm{O}_{2} \cdot 0.6 \mathrm{H}_{2} \mathrm{O}$} & Calcd & 75.41 & 7.98 & 8.24 \\
\hline & & Found & 75.36 & 8.14 & 8.56 \\
\hline \multirow{2}{*}{$(R)-6 a$} & \multirow{2}{*}{$\mathrm{C}_{32} \mathrm{H}_{39} \mathrm{~N}_{3} \mathrm{O}_{2} \quad 0.3 \mathrm{H}_{2} \mathrm{O}$} & Calcd & 76.40 & 7.93 & 8.35 \\
\hline & & Found & 76.85 & 8.16 & 8.40 \\
\hline \multirow{2}{*}{$6 b$} & \multirow{2}{*}{$\mathrm{C}_{31} \mathrm{H}_{35} \mathrm{Cl}_{2} \mathrm{~N}_{3} \mathrm{O}$} & Calcd & 69.40 & 6.58 & 7.83 \\
\hline & & Found & 69.10 & 6.66 & 7.72 \\
\hline \multirow[b]{2}{*}{$6 c$} & \multirow[b]{2}{*}{$\mathrm{C}_{32} \mathrm{H}_{38} \mathrm{ClN}_{3} \mathrm{O}_{2} \cdot 0.3 \mathrm{H}_{2} \mathrm{O}$} & Calcd & 71.42 & 7.24 & 7.81 \\
\hline & & Found & 71.51 & 7.09 & 7.85 \\
\hline \multirow{2}{*}{ 6d } & \multirow{2}{*}{$\mathrm{C}_{31} \mathrm{H}_{35} \mathrm{~F}_{2} \mathrm{~N}_{3} \mathrm{O} \quad 0.25 \mathrm{H}_{2} \mathrm{O}$} & Calcd & 73.28 & 7.04 & 8.27 \\
\hline & & Found & 73.02 & 6.93 & 8.29 \\
\hline
\end{tabular}

IR Spectroscopy:

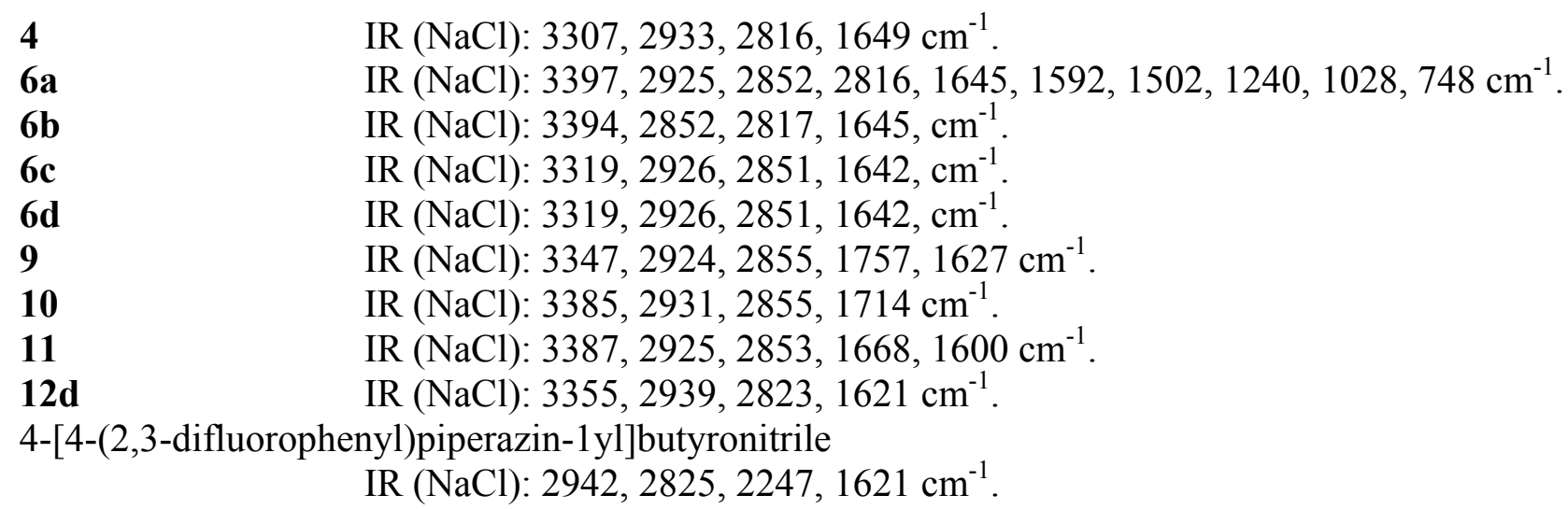


References:

(1) Wolinski, K.; Hinton, J. F.; Pulay, P. Efficient implementation of the gauge-independent atomic orbital method for NMR chemical shift calculations. Journal of the American Chemical Society 1990, $112,8251-8260$.

(2) Lenz, C.; Boeckler, F.; Hubner, H.; Gmeiner, P. Analogues of FAUC 73 revealing new insights into the structural requirements of nonaromatic dopamine D3 receptor agonists. Bioorganic \& Medicinal Chemistry 2004, 12, 113-117.

(3) Lenz, C.; Boeckler, F.; Hübner, H.; Gmeiner, P. Fancy bioisosteres: Synthesis, SAR, and pharmacological investigations of novel nonaromatic dopamine D3 receptor ligands. Bioorganic \& Medicinal Chemistry 2005, 13, 4434-4442. 